\title{
Origin, Succession, and Control of Biotoxin in Wine
}

\author{
Xiaoyu Xu, Tian Li, Yanyu Ji, Xia Jiang, Xuewei Shi* and Bin Wang* \\ School of Food Science and Technology, Shihezi University, Shihezi, China
}

Wine is a worldwide alcoholic beverage with antioxidant active substances and complex flavors. Moderate drinking of wine has been proven to be beneficial to health. However, wine has some negative components, such as residual pesticides, heavy metals, and biotoxins. Of these, biotoxins from microorganisms were characterized as the most important toxins in wine. Wine fermentation mainly involves alcoholic fermentation, malolactic fermentation, and aging, which endue wine with complex flavors and even produce some undesirable metabolites. These metabolites cause potential safety risks that are not thoroughly understood. This review aimed to investigate the origin, evolution, and control technology of undesirable metabolites (e.g., ochratoxin A, ethyl carbamate,

OPEN ACCESS

Edited by: Van-Tuan Tran, Vietnam National University, Hanoi, Vietnam

Reviewed by:

Pasquale Russo,

University of Foggia, Italy

Francisco Salinas,

Universidad Austral de Chile, Chile

*Correspondence:

Xuewei Shi

shixuewei@shzu.edu.cn

Bin Wang

binwang0228@shzu.edu.cn

Specialty section:

This article was submitted to

Food Microbiology,

a section of the journal

Frontiers in Microbiology

Received: 30 April 2021

Accepted: 22 June 2021

Published: 22 July 2021

Citation:

XU X, Li T, Ji Y, Jiang X, Shi X and Wang B (2021) Origin, Succession, and Control of Biotoxin in Wine.

Front. Microbiol. 12:703391. doi: 10.3389/fmicb.2021.703391 and biogenic amines) in wine. It also highlighted current wine industry practices of minimizing the number of biotoxins in wine.

Keywords: biogenic amines, biotoxin, ethyl carbamate, ochratoxin A, wine

\section{INTRODUCTION}

Wine is an alcoholic beverage made from fresh grapes or grape juice that undergoes complex biochemical changes in the presence of microorganisms. The wine originated in ancient Egypt or ancient Greece or the Greek island of Crete (Alebaki and Koutsouris, 2019). The wine industry has progressed globally since its development to date (Thorpe, 2009). Based on the geography, winemaking history, and winemaking tradition, some winemaking countries with a long history of production (mostly Europe and the Mediterranean region) are classified as "Old World," while the rising stars in the international market are classified as "New World" (emerging wine-producing countries outside of Europe, such as the United States, China, etc.) (Banks and Overton, 2010; Li et al., 2018). The three leading wine-producing countries worldwide are France, Italy, and Spain, which produce almost half of the world's wine (Schamel, 2006). According to the latest data from the International Organization of Vine and Wine (OIV), global wine production is estimated at 26 billion liters, and the wine trade continues to trend toward internationalization (OIV, 2020).

Nowadays, wine is attracting an increasing amount of attention due to its taste, aroma, and health benefits (Ditano-Vázquez et al., 2019; Rivera et al., 2019). While exploiting the various benefits of wine, its quality is often easily overlooked. Similar to other fermented foods, the fermentation process of wine creates a complex system of grape flavors and may also present some quality risks, such as heavy metals, pesticide residues, and biotoxins (Weng and Neethirajan, 2017). Among these, ethyl carbamate (EC) from yeast and lactic acid bacteria (LAB) (Uthurry et al., 2006; Du et al., 2018), biogenic amines (BAs) from LAB (García-Ruiz et al., 2011), and ochratoxin A (OTA) from mold (Iacumin et al., 2009) have gradually received attention in recent years. EC was shown to be a carcinogen as early as 1943 (Nettleship et al., 1943), and alcohol contributes to the 
carcinogenic effects of EC (Beland et al., 2005). BAs are also precursors to carcinogens (Guo et al., 2015), and hence their excessive intake can pose a threat to human health.

The production of high-quality wine has stringent requirements for grape raw materials (Morata et al., 2019), ferments, and grape processes, but their potential safety risks cannot be ignored. The risk factors of OTA, EC, and BAs have been identified in wine one after another; however, the sources of these risk factors and their evolution patterns are still unclear. This review focused on the dynamic changes in risk factors in wine fermentation, traced the risk factors, and proposed corresponding prevention and control to provide a theoretical basis for wine risk control.

\section{SAFETY RISKS AND COUNTERMEASURES IN WINE}

Moderate drinking of wine has been proven to be beneficial to health because wine comprises antioxidant active substances, minerals, and vitamins (Guilford and Pezzuto, 2011). However, wine can also have some negative components, such as residual pesticides (Guo T. et al., 2016), heavy metals (Bora et al., 2015), and some biotoxins. Of these, biotoxins from microorganisms were the most important toxins in wine (Vitali Čepo et al., 2018). These biotoxins can affect the drinking quality and food safety of wine and lead to a range of diseases if consumed in excess over a long period (Figure 1; Welke, 2019). The biotoxins of microbial origin in wine mainly comprise OTA, $\mathrm{EC}$, and BAs. The process from grapes to wines is long and complex, including transportation, pretreatment, maceration, and alcoholic fermentation (Ruiz et al., 2019). During wine fermentation, OTA, EC, and BAs undergo continuous evolution (Christaki and Tzia, 2002; Fernández-Segovia et al., 2014). Grape harvesting, maceration, alcoholic fermentation, and malolactic fermentation (MLF) involve the production of OTA. EC is always produced in alcoholic fermentation, MLF, and aging. Furthermore, various BAs are formed during MLF and aging (Figure 2).

\section{Ochratoxin A}

Ochratoxin is a mycotoxin composed of seven structurally similar compounds, including OTA, OTB, and OTC (Supplementary Figure 1). Among these, OTA is an IIB carcinogen, which has teratogenicity, nephrotoxicity, hepatotoxicity, neurotoxicity, and immunotoxicity to several kinds of animals (Silva et al., 2019). The OTA biosynthesis and the two possible key pathways involved are shown in Supplementary Figure 2 (Karlovsky, 1999; Gallo et al., 2017). OTA has attracted much attention because of its strong biological toxicity and potential pathogenicity in various cereal crops and fermented foods (Agriopoulou et al., 2020). As far as 1996, OTA was first identified in wine and then classified as the key mycotoxin in wine (Zimmerli and Dick, 1996). The European Commission set the maximum limit for OTA content in wine at $2 \mu \mathrm{g} / \mathrm{kg}$ (European Food Safety Authority (EFSA), 2006).
OTA is produced by various mycetes, including Aspergillus ochraceus, Penicillium verrucosum, Aspergillus niger, and Aspergillus carbonarius. However, the main fungal sources of OTA in grapes are $A$. carbonarius and A. niger (Oliveri et al., 2017). A. carbonarius has been considered as the most important ochratoxin-producing species in grapes because it is widespread on grapes and produces a high concentration of OTA (Varga and Kozakiewicz, 2006). Like other mycetes, Aspergillus spp. can produce spores, which are blown to the surrounding grape racks by wind and flying animals (Jiang et al., 2013). During the ripening of grapes, humid weather and high relative humidity can easily cause the rotting of grapes by providing favorable conditions for the growth of Aspergillus spp. (Cañas et al., 2008). Obviously, the environmental conditions of a vineyard play a key role in the contamination of ochratoxin-producing species in wine grapes, further leading to the accumulation of OTA in wine (Gil-Serna et al., 2018; Abarca et al., 2019). Before wine fermentation, the grape skin and pulp are crushed and macerated together, which is conducive to the release of OTA into the grape juice (Visconti et al., 2008). The OTA content changes greatly in the whole winemaking process (Anli and Bayram, 2009; Freire et al., 2020). Due to the different winemaking processes, red wines generally have higher OTA levels compared with white wines (Lasram et al., 2008; Dachery et al., 2017).

Some methods, such as avoiding mycete infection, degrading OTA, and adsorbing OTA, have been developed to decrease the contamination of OTA (Chen et al., 2018). Applying biological control methods to avoid mold infection during the storage of grapes after harvest and removing moldy grape clusters before fermentation can greatly reduce the possibility of toxinproducing fungal growth and production of OTA (Hocking et al., 2007; Gil-Serna et al., 2018). Inorganic adsorbents (such as zeolite and activated carbon) (Piotrowska et al., 2013; Abrunhosa et al., 2014) and microbial adsorbents (such as Saccharomyces spp., Rhodotorula spp., Lactobacillus spp., and Cryptococcus spp.) (Abrunhosa et al., 2010; Russo et al., 2016) reduce the OTA content through adsorbing or converting OTA into less toxic phenylalanine (Phe) and ochratoxin alpha (OT $\alpha)$. However, the application of these adsorbents in OTA control in wine is limited because they can adsorb phenolic compounds and pigments of wine to varying degrees, resulting in wine discoloration, besides adsorbing the risky OTA (Caridi, 2013; Petruzzi et al., 2015). Moreover, microbial-derived enzymes with carboxypeptidase A activity also affect the degradation of OTA (Amézqueta et al., 2009).

\section{Ethyl Carbamate}

As early as 1943, EC was classified as a Class 2A carcinogen by the International Agency for Research on Cancer of the World Health Organization (2007) (Conacher and Page, 1986; Zimmerli and Schlatter, 1991). EC is a carcinogenic compound involved, among others, in lung cancer, lymphoma, liver cancer, and skin cancer (Gowd et al., 2018). However, it is believed that EC widely occurs in traditional fermented foods ( $\mathrm{Li}$ and Bardají, 2017). EC has been recognized as one of the biggest challenges facing the alcoholic beverage industry since EC was 


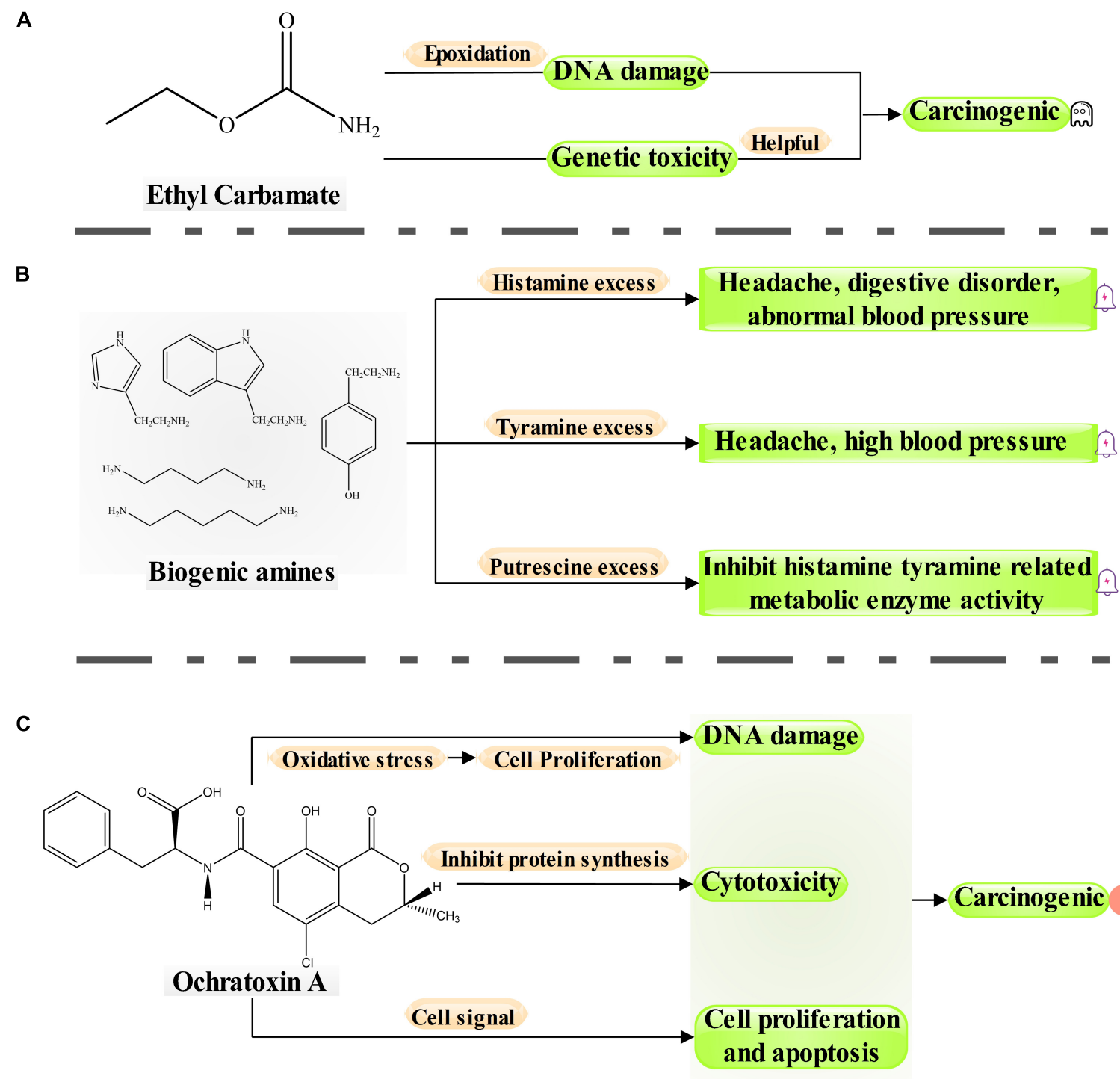

FIGURE 1 | Hazard process of biologically harmful products (ethyl carbamate, biogenic amines and ochratoxin A) in wine.

detected in alcoholic beverages in 1976 (Ough, 1976; Zhao et al., 2013a). Supplementary Figure 3 shows the possible pathways of the formation of EC and the mechanism of carcinogenesis (Zhao et al., 2013a). Different countries and organizations around the world have different standards for the concentration of EC in alcoholic beverages (Supplementary Table 1). Also, no unified maximum EC limit exists in the EU. However, the concentration of EC in $30.6 \%$ of wines exceeds $20 \mu \mathrm{g} / \mathrm{L}$ (standard of the Food and Agriculture Organization of the United Nations), which is a threat to the health of consumers and the sustainable development of the wine industry (Gowd et al., 2018).

EC is generally produced by the spontaneous reaction of ethanol and compounds containing carbamoyl groups (such as urea, citrulline, carbamoyl phosphate, and so on) (Jiao et al., 2014). Among these reactions, the urea formation pathway is believed to be the main formation pathway of EC (Zimmerli and Schlatter, 1991; Cerreti et al., 2016). Wine environments (such as temperature and acidity) and microorganisms can affect the production of EC during fermentation (Zhao et al., 2013a). During grape plantation, the application of nitrogen fertilizer increased the urea content, providing EC precursors in grapes (Garde-Cerdán et al., 2015). Furthermore, yeast and LAB produced a large amount of citrulline through the urea cycle pathway and the arginine deiminase metabolism pathway, respectively (Azevedo et al., 2002; Vrancken et al., 2009). During wine fermentation, some EC precursors have been released, increasing the urea content in wine (Mira de Orduña et al., 2000). The EC content in wine varied with grape varieties (Ubeda et al., 2020), grape maturity (Lago et al., 2017), pH value (Araque et al., 2013), EC precursor concentration (Zhao et al., 2013b), the volume fraction of ethanol (Araque et al., 2013), and ecological 


\section{Grape harvest}

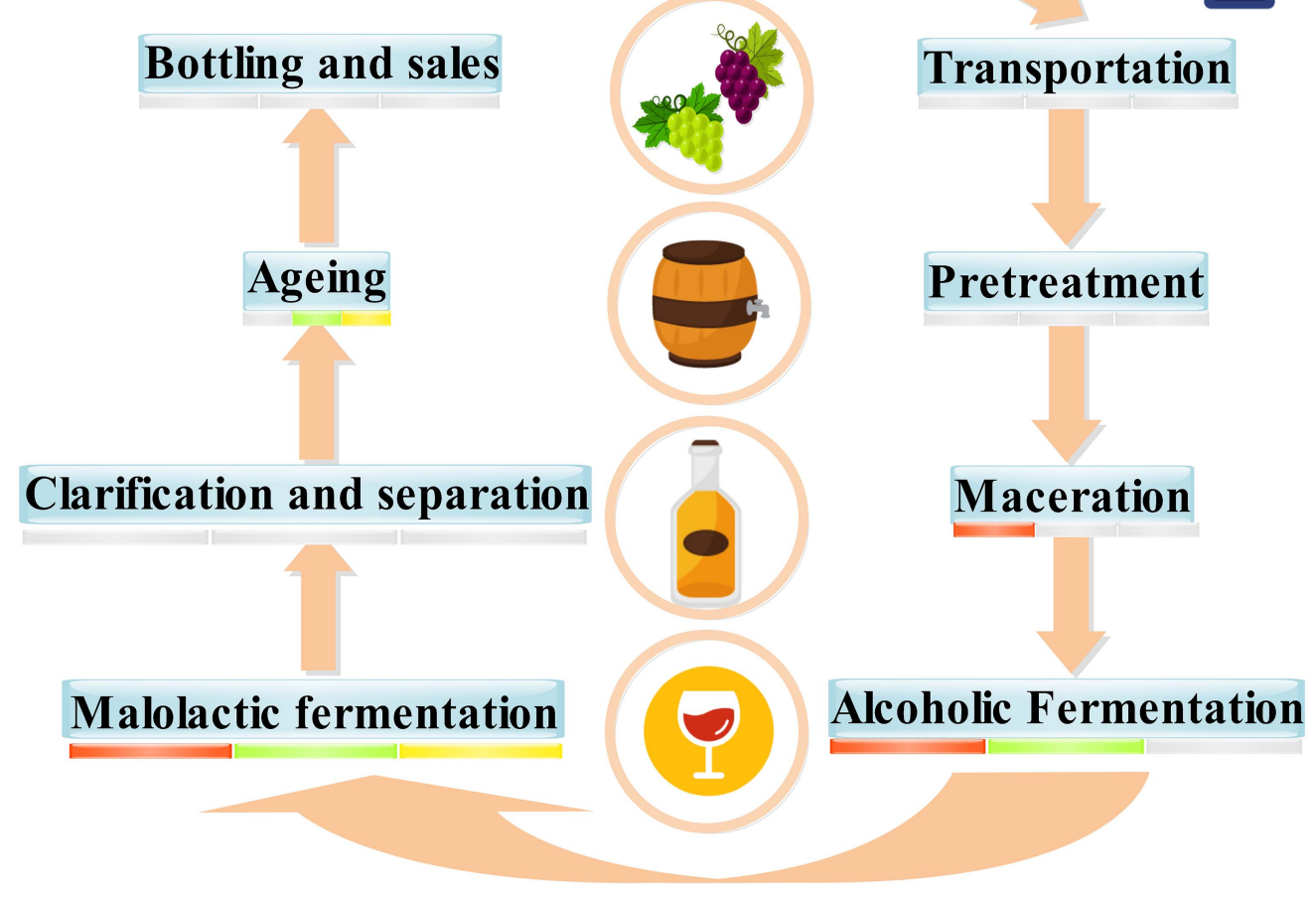

Ochratoxin A

Ethyl carbamate

Biogenic amines conditions (such as temperature, precipitation, and extreme climate) (Diamantidou et al., 2018).

Controlling the EC content in wine mainly focuses on yeast strains (Araque et al., 2013; Guo T. et al., 2016), grapes (Bell and Henschke, 2005), excipients (Bell and Henschke, 2005), and fermentation conditions (Stevens and Ough, 1993; Xue et al., 2015). The enhancement of genes encoding for enzymes involved in urea degradation and transport or the knockout of genes encoding for arginase allowed the selection of yeast strains with low urea production capacity and arginase activity (Araque et al., 2013; Guo X. W. et al., 2016). Properly adjusted vineyard management practices, such as fertilization, pruning, irrigation, and ground cover, can also control the EC content in wine to some extent (Soufleros et al., 2003). Without affecting the flavor of the wine, an appropriate reduction in temperature also helps reduce the EC content in the wine, which is a key adjustment point for EC control from a process perspective (Hasnip et al., 2004). Some studies showed that acid urease catalyzed the decomposition of urea to ammonia and carbon dioxide, decreasing the content of an important precursor of EC in wine (Cerreti et al., 2016; Liu et al., 2018; Yang et al., 2021). Since 1999, Europe has approved the use of acid urease extracted from fermented LAB in wine (Cerreti et al., 2016). However, urease is a metalloenzyme with nickel as a prosthetic group, which can lead to nickel residues in wine (Follmer et al., 2004). Furthermore, urea adsorbents, EC degrading enzymes, EC adsorbents, and so forth have been used as effective and potential agents to controlling the EC content in wine under the premise of ensuring the flavor characteristics of the original wine (Wu et al., 2014; Zhou et al., 2017).

\section{Biogenic Amines}

BAs are a class of low-molecular-weight nitrogen-containing organic compounds (Manetta et al., 2016). A physiological concentration of BAs is involved in important biological reactions in the human body (Cinquina et al., 2004). However, the excessive intake of exogenous BAs can lead to allergic reactions, such as headache, nausea, blood pressure changes, and respiratory disorders, and is even life-threatening (Spano et al., 2010). BAs include mainly tryptamine, cadaverine, tyramine, histamine, putrescine, spermidine, and spermine (Supplementary Table 2), which are usually produced after decarboxylation of the corresponding amino acids by different decarboxylases (Supplementary Figure 4; Wolken et al., 2006). As the most toxic BAs, histamine is regarded as a key indicator of the hygienic value during wine fermentation (Cunha et al., 2017). It can be broken down by two different oxidase enzymes (monoamine oxidase and diamine oxidase) (Seiler, 2004). However, ethanol is an inhibitor of diamine oxidase (histamine-degrading) at the gut level (García-Ruiz et al., 2011). Putrescine has been found to be one of the most abundant BAs in wine (Henríquez-Aedo et al., 2012; Cunha et al., 2017). 
Therefore, the BA content is more stringent in alcoholic foods compared with other fermented foods (Rollan et al., 1995; García-Ruiz et al., 2011). The European countries have set limits for histamine below $10 \mathrm{mg} / \mathrm{L}$ in wine, with Germany being the strictest (not higher than $2 \mathrm{mg} / \mathrm{L}$ ) (Smit et al., 2008; Costantini et al., 2019).

BAs are produced by microorganisms with amino acid decarboxylase activity in the presence of sufficient free amino acids at any stage of winemaking (Santos, 1996). The presence of precursors (amino acids) and microorganisms with decarboxylase activity are the main factors affecting the BA content (Landete et al., 2011; Russo et al., 2016). During winemaking, yeast strains weakly contribute to BA accumulation (Smit et al., 2013), but LAB responsible for MLF has been identified as the main producer of BAs in wine (Spano et al., 2010). For example, Oenococcus oeni, Lactobacillus hilgardii, and Pediococcus parvulus increased the BA content in wine through histamine accumulation (Özogul and Hamed, 2018). As one of the main catabolites from arginine degradation, putrescine has been identified as one of the most abundant BAs in wine, because arginine is the main amino acids in grapes (Henríquez-Aedo et al., 2012; Ortega-Heras et al., 2014; Cunha et al., 2017). O. oeni also contributes to putrescine accumulation after sequential degradation of arginine and ornithine (Pessione and Cirrincione, 2016). On the other hand, increasing $\mathrm{pH}$ can increase the number and variety of microorganisms, further enhancing the risk (Guo et al., 2015). The BA content in white wines is less than that in red wines because of a lower $\mathrm{pH}$ and the different winemaking processes (García-Marino et al., 2010).

The production of BAs is a strategy to obtain metabolic advantages to face certain stress conditions. Therefore, conditions encouraging the expression of decarboxylase genes should be avoided and controlled (Mohedano et al., 2015). Moreover, commercial starters with negative decarboxylase activity are also recommended (Gardini et al., 2016). Several authors have proposed that yeast can convert amino acids into fused alcohols through the well-known Ehrlich pathway during alcoholic fermentation, plausibly leading to a decrease in the BA content (Mas et al., 2014). In a sense, the presence of putrescine in wine seems inevitable, because the ornithine decarboxylation occurs simultaneously with MLF at a high speed (MartínezPinilla et al., 2013; Battistelli et al., 2020). Due to the presence of the indigenous strains capable of degrading arginine to ornithine, the use of the malolactic starters that are unable to degrade ornithine or arginine cannot completely avoid accumulation of putrescine (Pramateftaki et al., 2012). It is plausible that removing or inhibiting the activity of LAB immediately after MLF to avoid arginine degradation may be an effective method to reduce potential risk from putrescine in wine (Wunderlichová et al., 2014). Therefore, controlling microbiota is a good strategy to reduce BA production. García-Ruiz et al. (2011) found that nine strains belonging to the Lactobacillus and Pediococcus groups showed the greatest BA degradation capacity, the best being for L. casei IFI-CA52. Capozzi et al. (2012) have investigated that Lactobacillus plantarum NDT 09 and NDT 16 could enhance the overall aroma of wine and degrade putrescine and tyramine. Some yeasts were also capable of degrading BAs. Bäumlisberger et al. (2015) observed that some strains of Debaryomyces hansenii and Yarrowia lipolytica could degrade BAs. The degradation of BAs by the most efficient strain, D. hanseniii H525, could be attributed to a peroxisomal amine oxidase activity. Callejón et al. (2016) reported the employment of laccase to degrade BAs, which provides a new perspective on the use of microorganisms or purified microbial enzymes. Further research should be conducted to find new strains capable of degrading BAs. Also, histamine, putrescine, cadaverine, spermine, and spermidine in wine can be adsorbed and removed by phosphonic acid and sulfonic acid bifunctional mesoporous silica materials, which may also be an effective way to reduce the BA content in wine in the future (Rodríguez-Bencomo et al., 2020).

\section{CONCLUSION AND FUTURE PERSPECTIVES}

The quality and safety risks of wine involve many links. To ensure food safety and improve the quality of wine, we need to control the contamination of raw materials, strictly select winemaking microorganisms, and control the fermentation and post-management processes. The study of the origin, evolution, and control techniques of undesirable metabolites in wine (OTA, $\mathrm{EC}$, and BAs) can reduce not only the quality hazards of wine but also the economic losses due to microbial spoilage. In the future, we should pay attention to various potentially harmful substances that have pathogenic effects on human beings during the grape growth and winemaking process, and implement effective prevention and control through testing. In summary, only by clarifying the factors that affect the quality of winemaking can we ensure a clear direction for quality management and ultimately a quality wine production.

\section{AUTHOR CONTRIBUTIONS}

XX wrote the main manuscript. TL and YJ conceived the framework of the manuscript. XJ contributed to the pictures in the manuscript. XS and BW coordinated contributions and provided the final draft of the manuscript. All authors commented on the manuscript at all stages.

\section{FUNDING}

This study was supported by the Xinjiang Production and Construction Corps (Nos. 2019AB025 and 2020AB014), the Shihezi Science and Technology Bureau (No. 2020GY07), the Shuanghe Science and Technology Bureau (No. 20GY01), and the National Natural Science Foundation of China (No. 31960465).

\section{SUPPLEMENTARY MATERIAL}

The Supplementary Material for this article can be found online at: https://www.frontiersin.org/articles/10.3389/fmicb.2021. 703391/full\#supplementary-material 


\section{REFERENCES}

Abarca, M. L., Bragulat, M. R., Castellá, G., and Cabañes, F. J. (2019). Impact of some environmental factors on growth and ochratoxin A production by Aspergillus niger and Aspergillus welwitschiae. Int. J. Food Microbiol. 291, 10-16. doi: 10.1016/j.ijfoodmicro.2018.11.001

Abrunhosa, L., Inês, A., Rodrigues, A. I., Guimarães, A., Pereira, V. L., Parpot, P., et al. (2014). Biodegradation of ochratoxin A by Pediococcus parvulus isolated from Douro wines. Int. J. Food Microbiol. 188, 45-52. doi: 10.1016/j. ijfoodmicro.2014.07.019

Abrunhosa, L., Paterson, R. R., and Venâncio, A. (2010). Biodegradation of ochratoxin A for food and feed decontamination. Toxins 2, 1078-1099. doi: 10.3390/toxins 2051078

Agriopoulou, S., Stamatelopoulou, E., and Varzakas, T. (2020). Advances in occurrence, importance, and mycotoxin control strategies: prevention and detoxification in foods. Foods 9:137. doi: 10.3390/foods9020137

Alebaki, M., and Koutsouris, A. (2019). "Wine tourism destinations across the life-cycle: a comparison of Northern Greece, Peloponnese and Crete," in Wine Tourism Destination Management and Marketing: Theory and Cases, eds M. Sigala and R. N. S. Robinson (Cham: Springer International Publishing), 463482. doi: 10.1007/978-3-030-00437-8_29

Amézqueta, S., González-Peñas, E., Murillo-Arbizu, M., and de Cerain, A. L. (2009). Ochratoxin A decontamination: a review. Food Control 20, 326-333. doi: 10.1016/j.foodcont.2008.05.017

Anli, E., and Bayram, M. (2009). Ochratoxin A in wines. Food Rev. Int. 25, 214-232. doi: $10.1080 / 87559120902956182$

Araque, I., Bordons, A., and Reguant, C. (2013). Effect of ethanol and low pH on citrulline and ornithine excretion and arc gene expression by strains of Lactobacillus brevis and Pediococcus pentosaceus. Food Microbiol. 33, 107-113. doi: 10.1016/j.fm.2012.09.005

Azevedo, Z., Couto, J. A., and Hogg, T. (2002). Citrulline as the main precursor of ethyl carbamate in model fortified wines inoculated with Lactobacillus hilgardii: a marker of the levels in a spoiled fortified wine. Lett. Appl. Microbiol.34, 32-36. doi: 10.1046/j.1472-765x.2002.01045.x

Banks, G., and Overton, J. (2010). Old world, new world, third world? Reconceptualising the worlds of wine. J. Wine Res. 21, 57-75. doi: 10.1080/ 09571264.2010.495854

Battistelli, N., Perpetuini, G., Perla, C., Arfelli, G., Zulli, C., Rossetti, A. P., et al. (2020). Characterization of natural Oenococcus oeni strains for Montepulciano d'Abruzzo organic wine production. Eur. Food Res. Technol. 246, 1031-1039. doi: 10.1007/s00217-020-03466-3

Bäumlisberger, M., Moellecken, U., König, H., and Claus, H. (2015). The potential of the yeast Debaryomyces hansenii H525 to degrade biogenic amines in food. Microorganisms 3, 839-850. doi: 10.3390/microorganisms30 40839

Beland, F. A., Benson, R. W., Mellick, P. W., Kovatch, R. M., Roberts, D. W., Fang, J.-L., et al. (2005). Effect of ethanol on the tumorigenicity of urethane (ethyl carbamate) in B6C3F1 mice. Food Chem. Toxicol. 43, 1-19. doi: 10.1016/j.fct. 2004.07.018

Bell, S. J., and Henschke, P. A. (2005). Implications of nitrogen nutrition for grapes, fermentation and wine. Aust. J. Grape Wine Res. 11, 242-295. doi: 10.1111/j. 1755-0238.2005.tb00028.x

Bora, F. D., Bunea, C. I., Rusu, T., and Pop, N. (2015). Vertical distribution and analysis of micro-, macroelements and heavy metals in the system soilgrapevine-wine in vineyard from North-West Romania. Chem. Cent. J. 9:19. doi: 10.1186/s13065-015-0095-2

Callejón, S., Sendra, R., Ferrer, S., and Pardo, I. (2016). Cloning and characterization of a new laccase from Lactobacillus plantarum J16 CECT 8944 catalyzing biogenic amines degradation. Appl. Microbiol. Biotechnol. 100, 3113-3124.

Cañas, P. I., Romero, E. G., Alonso, S. G., González, M. F., and Herreros, M. P. (2008). Amino acids and biogenic amines during spontaneous malolactic fermentation in Tempranillo red wines. J. Food Compos. Anal. 21, 731-735. doi: 10.1016/j.jfca.2007.11.002

Capozzi, V., Russo, P., Ladero, V., Fernández, M., Fiocco, D., Alvarez, M. A., et al. (2012). Biogenic amines degradation by Lactobacillus plantarum: toward a potential application in wine. Front. Microbiol. 3:122. doi: 10.3389/fmicb.2012. 00122
Caridi, A. (2013). Improved screening method for the selection of wine yeasts based on their pigment adsorption activity. Food Technol. Biotech. 51, 137-144. doi: $10.1155 / 2013 / 578781$

Cerreti, M., Fidaleo, M., Benucci, I., Liburdi, K., Tamborra, P., and Moresi, M. (2016). Assessing the potential content of ethyl carbamate in white, red, and rosé wines as a key factor for pursuing urea degradation by purified acid urease. Afr. J. Food Sci. 81, C1603-C1612. doi: 10.1111/1750-3841.13344

Chen, W., Li, C., Zhang, B., Zhou, Z., Shen, Y., Liao, X., et al. (2018). Advances in biodetoxification of ochratoxin A-a review of the past five decades. Front. Microbiol. 9:1386. doi: 10.3389/fmicb.2018.01386

Christaki, T., and Tzia, C. (2002). Quality and safety assurance in winemaking. Food Control 13, 503-517. doi: 10.1016/S0956-7135(02)00030-0

Cinquina, A. L., Calı, A., Longo, F., De Santis, L., Severoni, A., and Abballe, F. (2004). Determination of biogenic amines in fish tissues by ion-exchange chromatography with conductivity detection. J. Chromatogr. A 1032, 73-77. doi: 10.1016/j.chroma.2004.01.013

Conacher, H. B. S., and Page, B. D. (1986). Ethyl carbamate in alcoholic beverages, a canadian case history; proceedings of the euro food toxicity, interdisciplinary conference on natural toxicants in food. Eur. Soc. Toxicol. 1, 237-242.

Costantini, A., Vaudano, E., Pulcini, L., Carafa, T., and Garcia-Moruno, E. (2019). An overview on biogenic amines in wine. Beverages 5:19. doi: 10.3390/ beverages5010019

Cunha, S. C., Lopes, R., and Fernandes, J. O. (2017). Biogenic amines in liqueurs: influence of processing and composition. J. Food Compos. Anal. 56, 147-155. doi: 10.1016/j.jfca.2016.11.016

Dachery, B., Veras, F. F., Dal Magro, L., Manfroi, V., and Welke, J. E. (2017). Exposure risk assessment to ochratoxin A through consumption of juice and wine considering the effect of steam extraction time and vinification stages. Food Chem. Toxicol. 109, 237-244. doi: 10.1016/j.fct.2017.09.013

Diamantidou, D., Zotou, A., and Theodoridis, G. (2018). Wine and grape marc spirits metabolomics. Metabolomics 14:159. doi: 10.1007/s11306-018-1458- 1

Ditano-Vázquez, P., Torres-Peña, J. D., Galeano-Valle, F., Pérez-Caballero, A. I., Demelo-Rodríguez, P., Lopez-Miranda, J., et al. (2019). The fluid aspect of the mediterranean diet in the prevention and management of cardiovascular disease and diabetes: the role of polyphenol content in moderate consumption of wine and olive oil. Nutrients 11:2833. doi: 10.3390/nu11112833

Du, H., Song, Z., and Xu, Y. (2018). Ethyl carbamate formation regulated by lactic acid bacteria and nonconventional yeasts in solid-state fermentation of Chinese Moutai-flavor liquor. J. Agric. Food Chem. 66, 387-392. doi: 10.1021/acs.jafc. $7 \mathrm{~b} 05034$

European Food Safety Authority (EFSA) (2006). Opinion of the scientific panel on contaminants in the food chain on a request (from) commission related to Ochratoxin A in food. EFSA J. 365, 1-56.

Fernández-Segovia, I., Pérez-Llácer, A., Peidro, B., and Fuentes, A. (2014). Implementation of a food safety management system according to ISO 22000 in the food supplement industry: a case study. Food Control 43, 28-34. doi: 10.1016/j.foodcont.2014.02.042

Follmer, C., Pereira, F. V., Da Silveira, N. P., and Carlini, C. R. (2004). Jack bean urease (EC 3.5. 1.5) aggregation monitored by dynamic and static light scattering. Biophys. Chem. 111, 79-87. doi: 10.1016/j.bpc.2004.03.009

Freire, L., Braga, P. A., Furtado, M. M., Delafiori, J., Dias-Audibert, F. L., Pereira, G. E., et al. (2020). From grape to wine: fate of ochratoxin A during red, rose, and white winemaking process and the presence of ochratoxin derivatives in the final products. Food Control 113:107167. doi: 10.1016/j.foodcont.2020. 107167

Gallo, A., Ferrara, M., and Perrone, G. (2017). Recent advances on the molecular aspects of ochratoxin A biosynthesis. Curr. Opin. Food Sci. 17, 49-56. doi: 10.1016/j.cofs.2017.09.011

García-Marino, M., Trigueros, Á, and Escribano-Bailón, T. (2010). Influence of oenological practices on the formation of biogenic amines in quality red wines. J. Food Compos. Anal. 23, 455-462. doi: 10.1016/j.jfca.2010.02.003

García-Ruiz, A., González-Rompinelli, E. M., Bartolomé, B., and MorenoArribas, M. V. (2011). Potential of wine-associated lactic acid bacteria to degrade biogenic amines. Int. J. Food Microbiol. 148, 115-120. doi: 10.1016/j. ijfoodmicro.2011.05.009

Garde-Cerdán, T., Santamaría, P., Rubio-Bretón, P., González-Arenzana, L., López-Alfaro, I., and López, R. (2015). Foliar application of proline, phenylalanine, and urea to Tempranillo vines: effect on grape volatile 
composition and comparison with the use of commercial nitrogen fertilizers. LWT Food Sci. Technol. 60, 684-689. doi: 10.1016/j.lwt.2014.10.028

Gardini, F., Özogul, Y., Suzzi, G., Tabanelli, G., and Özogul, F. (2016). Technological factors affecting biogenic amine content in foods: a review. Front. Microbiol. 7:1218. doi: 10.3389/fmicb.2016.01218

Gil-Serna, J., Vázquez, C., González-Jaén, M. T., and Patiño, B. (2018). Wine contamination with ochratoxins: a review. Beverages 4:6. doi: 10.3390/ beverages 4010006

Gowd, V., Su, H., Karlovsky, P., and Chen, W. (2018). Ethyl carbamate: an emerging food and environmental toxicant. Food Chem. 248, 312-321. doi: 10.1016/j.foodchem.2017.12.072

Guilford, J. M., and Pezzuto, J. M. (2011). Wine and health: a review. Am. J. Enol. Viticult. 62:471. doi: 10.5344/ajev.2011.11013

Guo, T., Fang, P., Jiang, J., Zhang, F., Yong, W., Liu, J., et al. (2016). Rapid screening and quantification of residual pesticides and illegal adulterants in red wine by direct analysis in real time mass spectrometry. J. Chromatogr. A 1471, 27-33. doi: 10.1016/j.chroma.2016.09.073

Guo, X. W., Li, Y. Z., Guo, J., Wang, Q., Huang, S. Y., Chen, Y. F., et al. (2016). Reduced production of ethyl carbamate for wine fermentation by deleting CAR1 in Saccharomyces cerevisiae. J. Ind. Microbiol. Biotechnol. 43, 671-679. doi: 10.1007/s10295-016-1737-7

Guo, Y. Y., Yang, Y. P., Peng, Q., and Han, Y. (2015). Biogenic amines in wine: a review. Int. J. Food Sci. Technol. 50, 1523-1532. doi: 10.1111/ijfs.12833

Hasnip, S., Caputi, A., Crews, C., and Brereton, P. (2004). Effects of storage time and temperature on the concentration of ethyl carbamate and its precursors in wine. Food Addit. Contam. 21, 1155-1161. doi: 10.1080/02652030400019851

Henríquez-Aedo, K., Vega, M., Prieto-Rodríguez, S., and Aranda, M. (2012). Evaluation of biogenic amines content in Chilean reserve varietal wines. Food Chem. Toxicol. 50, 2742-2750. doi: 10.1016/j.fct.2012.05.034

Hocking, A. D., Leong, S. L., Kazi, B. A., Emmett, R. W., and Scott, E. S. (2007). Fungi and mycotoxins in vineyards and grape products. Int. J. Food Microbiol. 119, 84-88. doi: 10.1016/j.ijfoodmicro.2007.07.031

Iacumin, L., Chiesa, L., Boscolo, D., Manzano, M., Cantoni, C., Orlic, S., et al. (2009). Moulds and ochratoxin A on surfaces of artisanal and industrial dry sausages. Food Microbiol. 26, 65-70. doi: 10.1016/j.fm.2008.07.006

Jiang, C., Shi, J., and Zhu, C. (2013). Fruit spoilage and ochratoxin a production by Aspergillus carbonarius in the berries of different grape cultivars. Food Control 30, 93-100. doi: 10.1016/j.foodcont.2012.07.039

Jiao, Z., Dong, Y., and Chen, Q. (2014). Ethyl carbamate in fermented beverages: presence, analytical chemistry, formation mechanism, and mitigation proposals. Compr. Rev. Food Sci. Food Saf. 13, 611-626. doi: 10.1111/1541-4337.12084

Karlovsky, P. (1999). Biological detoxification of fungal toxins and its use in plant breeding, feed and food production. Nat. Toxins 7, 1-23. doi: 10.1002/(SICI) 1522-7189(199902)7:1<1::AID-NT37<3.0.CO;2-9

Lago, L. O., Nicolli, K. P., Marques, A. B., Zini, C. A., and Welke, J. E. (2017). Influence of ripeness and maceration of the grapes on levels of furan and carbonyl compounds in wine-simultaneous quantitative determination and assessment of the exposure risk to these compounds. Food Chem. 230, 594-603. doi: 10.1016/j.foodchem.2017.03.090

Landete, J. M., de las Rivas, B., Marcobal, A., and Muñoz, R. (2011). PCR methods for the detection of biogenic amine-producing bacteria on wine. Ann. Microbiol. 61, 159-166. doi: 10.1007/s13213-010-0068-6

Lasram, S., Mani, A., Zaied, C., Chebil, S., Abid, S., Bacha, H., et al. (2008). Evolution of ochratoxin A content during red and rose vinification. J. Sci. Food Agric. 88, 1696-1703. doi: 10.1002/jsfa.3266

Li, H., Wang, H., Li, H., Goodman, S., van der Lee, P., Xu, Z., et al. (2018). The worlds of wine: old, new and ancient. Wine Econ. Policy 7, 178-182. doi: 10.1016/j.wep.2018.10.002

Li, Y., and Bardají, I. (2017). A new wine superpower? An analysis of the Chinese wine industry. Cah. Agric. 26:65002. doi: 10.1051/cagri/2017051

Liu, Q., Yao, X., Liang, Q., Li, J., Fang, F., Du, G., et al. (2018). Molecular engineering of Bacillus paralicheniformis acid urease to degrade urea and ethyl carbamate in model Chinese rice wine. J. Agric. Food Chem. 66, 13011-13019. doi: $10.1021 /$ acs.jafc. 8 b04566

Manetta, A. C., Di Giuseppe, L., Tofalo, R., Martuscelli, M., Schirone, M., Giammarco, M., et al. (2016). Evaluation of biogenic amines in wine: determination by an improved HPLC-PDA method. Food Control 62, 351-356. doi: 10.1016/j.foodcont.2015.11.009

Martínez-Pinilla, O., Guadalupe, Z., Hernández, Z., and Ayestarán, B. (2013). Amino acids and biogenic amines in red varietal wines: the role of grape variety, malolactic fermentation and vintage. Eur. Food Res. Technol. 237, 887-895. doi: 10.1007/s00217-013-2059-x

Mas, A., Guillamon, J. M., Torija, M. J., Beltran, G., Cerezo, A. B., Troncoso, A. M., et al. (2014). Bioactive compounds derived from the yeast metabolism of aromatic amino acids during alcoholic fermentation. BioMed. Res. Int. 2014:898045. doi: 10.1155/2014/898045

Mira de Orduña, R., Liu, S. Q., Patchett, M. L., and Pilone, G. J. (2000). Ethyl carbamate precursor citrulline formation from arginine degradation by malolactic wine lactic acid bacteria. FEMS Microbiol. Lett. 183, 31-35. doi: 10.1111/j.1574-6968.2000.tb08929.x

Mohedano, M. L., López, P., Spano, G., and Russo, P. (2015). "Controlling the formation of biogenic amines in fermented foods," in Advances in Fermented Foods and Beverages, ed. W. Holzapfel (Sawston: Woodhead Publishing), 273310 .

Morata, A., Bañuelos, M. A., Vaquero, C., Loira, I., Cuerda, R., Palomero, F., et al. (2019). Lachancea thermotolerans as a tool to improve $\mathrm{pH}$ in red wines from warm regions. Eur. Food Res. Technol. 245, 885-894. doi: 10.1007/s00217-01903229-9

Nettleship, A., Henshaw, P. S., and Meyer, H. L. (1943). Induction of pulmonary tumors in mice with ethyl carbamate (urethane). J. Natl. Cancer Inst. 4, 309-319. doi: $10.1093 /$ jnci/4.3.309

OIV (2020). State of the World Vitivinicultural Sector in 2020. Available online at: https://www.oiv.int/en/oiv-life/2020-a-year-of-resilience (accessed April 20, 2021)

Oliveri, C., Bella, P., Tessitori, M., Catara, V., and La Rosa, R. (2017). Grape and environmental mycoflora monitoring in old, traditionally cultivated vineyards on Mount Etna, southern Italy. J. Sci. Food Agric. 97, 65-73. doi: 10.1002/jsfa. 7683

Ortega-Heras, M., Pérez-Magariño, S., Del-Villar-Garrachón, V., GonzálezHuerta, C., Moro Gonzalez, L. C., Guadarrama Rodríguez, A., et al. (2014). Study of the effect of vintage, maturity degree, and irrigation on the amino acid and biogenic amine content of a white wine from the Verdejo variety. J. Sci. Food Agric. 94, 2073-2082. doi: 10.1002/jsfa.6526

Ough, C. S. (1976). Ethyl carbamate in fermented beverages and foods. I. Naturally occurring ethylcarbamate. J. Agric. Food. Chem. 24, 323-328. doi: 10.1021/ jf60204a033

Özogul, F., and Hamed, I. (2018). The importance of lactic acid bacteria for the prevention of bacterial growth and their biogenic amines formation: a review. Crit. Rev. Food Sci. Nutr. 58, 1660-1670. doi: 10.1080/10408398.2016.1277972

Pessione, E., and Cirrincione, S. (2016). Bioactive molecules released in food by lactic acid bacteria: encrypted peptides and biogenic amines. Front. Microbiol. 7:876. doi: 10.3389/fmicb.2016.00876

Petruzzi, L., Baiano, A., De Gianni, A., Sinigaglia, M., Corbo, M. R., and Bevilacqua, A. (2015). Differential adsorption of ochratoxin A and anthocyanins by inactivated yeasts and yeast cell walls during simulation of wine aging. Toxins 7, 4350-4365. doi: 10.3390/toxins7104350

Piotrowska, M., Nowak, A., and Czyzowska, A. (2013). Removal of ochratoxin A by wine Saccharomyces cerevisiae strains. Eur. Food Res. Technol. 236, 441-447. doi: 10.1007/s00217-012-1908-3

Pramateftaki, P. V., Metafa, M., Karapetrou, G., and Marmaras, G. (2012). Assessment of the genetic polymorphism and biogenic amine production of indigenous Oenococcus oeni strains isolated from Greek red wines. Food Microbiol. 29, 113-120. doi: 10.1016/j.fm.2011. 09.007

Rivera, K., Salas-Pérez, F., Echeverría, G., Urquiaga, I., Dicenta, S., Pérez, D., et al. (2019). Red wine grape pomace attenuates atherosclerosis and myocardial damage and increases survival in association with improved plasma antioxidant activity in a murine model of lethal ischemic heart disease. Nutrients 11:2135. doi: 10.3390/nu11092135

Rodríguez-Bencomo, J. J., Rigou, P., Mattivi, F., López, F., and Mehdi, A. (2020). Removal of biogenic amines from wines by chemisorption on functionalized silica and effects on other wine components. Sci. Rep. 10:17279. doi: 10.1038/ s41598-020-74287-3 
Rollan, G. C., Coton, E., and Lonvaud-Funel, A. (1995). Histidine decarboxylase activity of Leuconostoc oenos 9204. Food Microbiol. 12, 455-461. doi: 10.1016/ S0740-0020(95)80130-8

Ruiz, J., Kiene, F., Belda, I., Fracassetti, D., Marquina, D., Navascués, E., et al. (2019). Effects on varietal aromas during wine making: a review of the impact of varietal aromas on the flavor of wine. Appl. Microbiol. Biotechnol. 103, 7425-7450. doi: 10.1007/s00253-019-10008-9

Russo, P., Capozzi, V., Spano, G., Corbo, M. R., Sinigaglia, M., and Bevilacqua, A. (2016). Metabolites of microbial origin with an impact on health: ochratoxin A and biogenic amines. Front. Microbiol. 7:482. doi: 10.3389/fmicb.2016.00482

Santos, M. S. (1996). Biogenic amines: their importance in foods. Int. J. Food Microbiol. 29, 213-231. doi: 10.1016/0168-1605(95)00032-1

Schamel, G. (2006). Geography versus brands in a global wine market. Agribusiness 22, 363-374. doi: 10.1002/agr.20091

Seiler, N. (2004). Catabolism of polyamines. Amino Acids 26, 217-233. doi: 10. 1007/s00726-004-0070-z

Silva, L. J. G., Rodrigues, A. P., Pereira, A. M. P. T., Lino, C. M., and Pena, A. (2019). Ochratoxin A in the Portuguese wine market, occurrence and risk assessment. Food Addit. Contam. B 12, 145-149. doi: 10.1080/19393210.2019.1595169

Smit, A. Y., du Toit, W. J., Stander, M., and du Toit, M. (2013). Evaluating the influence of maceration practices on biogenic amine formation in wine. LWT Food Sci. Technol. 53, 297-307. doi: 10.1016/j.lwt.2013.01.006

Smit, A., du Toit, W., and Du Toit, M. (2008). Biogenic amines in wine: understanding the headache. S. Afr. J. Enol. Vitic. 29, 109-127. doi: 10.21548/ 29-2-1444

Soufleros, E. H., Bouloumpasi, E., Tsarchopoulos, C., and Biliaderis, C. G. (2003). Primary amino acid profiles of Greek white wines and their use in classification according to variety, origin and vintage. Food Chem. 80, 261-273. doi: 10.1016/ S0308-8146(02)00271-6

Spano, G., Russo, P., Lonvaud-Funel, A., Lucas, P., Alexandre, H., Grandvalet, C., et al. (2010). Biogenic amines in fermented foods. Eur. J. Clin. Nutr. 64, S95-S100. doi: 10.1038/ejcn.2010.218

Stevens, D. F., and Ough, C. S. (1993). Ethyl carbamate formation: reaction of urea and citrulline with ethanol in wine under low to normal temperature conditions. Am. J. Enol. Viticult. 44, 309-312. doi: 10.1016/S0065-2164(08) 70598-7

Thorpe, M. (2009). The globalisation of the wine industry: new world, old world and China. China Agr. Econ. Rev. 1, 301-313. doi: 10.1108/17561370910958873

Ubeda, C., Hornedo-Ortega, R., Cerezo, A. B., Garcia-Parrilla, M. C., and Troncoso, A. M. (2020). Chemical hazards in grapes and wine, climate change and challenges to face. Food Chem. 314:126222. doi: 10.1016/j.foodchem.2020. 126222

Uthurry, C. A., Lepe, J. A. S., Lombardero, J., and García Del Hierro, J. R. (2006). Ethyl carbamate production by selected yeasts and lactic acid bacteria in red wine. Food Chem. 94, 262-270. doi: 10.1016/j.foodchem.2004.11.017

Varga, J., and Kozakiewicz, Z. (2006). Ochratoxin A in grapes and grapederived products. Trends Food Sci. Technol. 17, 72-81. doi: 10.1016/j.tifs.2005. 10.007

Visconti, A., Perrone, G., Cozzi, G., and Solfrizzo, M. (2008). Managing ochratoxin A risk in the grape-wine food chain. Food Addit. Contam. A 25, 193-202. doi: 10.1080/02652030701744546

Vitali Čepo, D., Pelajić, M., Vinković Vrček, I., Krivohlavek, A., Žuntar, I., and Karoglan, M. (2018). Differences in the levels of pesticides, metals, sulphites and ochratoxin A between organically and conventionally produced wines. Food Chem. 246, 394-403. doi: 10.1016/j.foodchem.2017.10.133

Vrancken, G., Rimaux, T., Weckx, S., De Vuyst, L., and Leroy, F. (2009). Environmental $\mathrm{pH}$ determines citrulline and ornithine release through the arginine deiminase pathway in Lactobacillus fermentum IMDO 130101. Int. J. Food Microbiol. 135, 216-222. doi: 10.1002/bit.260480111

Welke, J. E. (2019). Fungal and mycotoxin problems in grape juice and wine industries. Curr. Opin. Food Sci. 29, 7-13. doi: 10.1016/j.cofs.2019.06.009

Weng, X., and Neethirajan, S. (2017). Ensuring food safety: quality monitoring using microfluidics. Trends Food Sci. Technol. 65, 10-22. doi: 10.1016/j.tifs. 2017.04.015

Wolken, W. A., Lucas, P. M., Lonvaud-Funel, A., and Lolkema, J. S. (2006). The mechanism of the tyrosine transporter TyrP supports a proton motive tyrosine decarboxylation pathway in Lactobacillus brevis. J. Bacteriol. 188, 2198-2206. doi: 10.1128/JB.188.6.2198-2206.2006

Wu, P., Cai, C., Shen, X., Wang, L., Zhang, J., Tan, Y., et al. (2014). Formation of ethyl carbamate and changes during fermentation and storage of yellow rice wine. Food Chem. 152, 108-112. doi: 10.1016/j.foodchem.2013.11.135

Wunderlichová, L., Buňková, L., Koutný, M., Jančová, P., and Buňka, F. (2014). Formation, degradation, and detoxification of putrescine by foodborne bacteria: a review. Compr. Rev Food Sci. Food Saf. 13, 1012-1030. doi: 10.1111/15414337.12099

Xue, J., Fu, F., Liang, M., Zhao, C., Wang, D., and Wu, Y. (2015). Ethyl carbamate production kinetics during wine storage. S. Afr. J. Enol. Vitic. 36, 277-284.

Yang, H., Cai, G., Lu, J., and Gómez Plaza, E. (2021). The production and application of enzymes related to the quality of fruit wine. Crit. Rev. Food Sci. Nutr. 61, 1605-1615. doi: 10.1080/10408398.2020.1763251

Zhao, X., Du, G., Zou, H., Fu, J., Zhou, J., and Chen, J. (2013a). Progress in preventing the accumulation of ethyl carbamate in alcoholic beverages. Trends Food Sci. Technol. 32, 97-107. doi: 10.1016/j.tifs.2013.05.009

Zhao, X., Zou, H., Fu, J., Chen, J., Zhou, J., and Du, G. J. Y. (2013b). Nitrogen regulation involved in the accumulation of urea in Saccharomyces cerevisiae. Yeast 30, 437-447. doi: 10.1002/yea.2980

Zhou, W., Fang, R., and Chen, Q. (2017). Effect of gallic and protocatechuic acids on the metabolism of ethyl carbamate in Chinese yellow rice wine brewing. Food Chem. 233, 174-181. doi: 10.1016/j.foodchem.2017.04.113

Zimmerli, B., and Dick, R. (1996). Ochratoxin A in table wine and grape-juice: occurrence and risk assessment. Food Addit. Contam. 13, 655-668. doi: 10.1080/ 02652039609374451

Zimmerli, B., and Schlatter, J. (1991). Ethyl carbamate: analytical methodology, occurrence, formation, biological activity and risk assessment. Mutat. Res. 259, 325-350. doi: 10.1016/0165-1218(91)90126-7

Conflict of Interest: The authors declare that the research was conducted in the absence of any commercial or financial relationships that could be construed as a potential conflict of interest.

Copyright (C) $2021 \mathrm{Xu}, \mathrm{Li}$, Ji, Jiang, Shi and Wang. This is an open-access article distributed under the terms of the Creative Commons Attribution License (CC BY). The use, distribution or reproduction in other forums is permitted, provided the original author(s) and the copyright owner(s) are credited and that the original publication in this journal is cited, in accordance with accepted academic practice. No use, distribution or reproduction is permitted which does not comply with these terms. 